Article

\title{
Impacts of Environmental Certificate and Pollution Abatement Equipment on SMEs' Performance: An Empirical Case in Vietnam
}

\author{
Jung-Fa Tsai ${ }^{1}$, Phi-Hung Nguyen ${ }^{1,2}{ }^{\oplus}$, Ming-Hua Lin ${ }^{3, *}$, Duy-Van Nguyen ${ }^{4}{ }^{\oplus}$, Hsu-Hao Lin ${ }^{2}$ \\ and Anh-Tuan Ngo ${ }^{2}$ (I)
}

1 Department of Business Management, National Taipei University of Technology, Taipei 10608, Taiwan; jftsai@ntut.edu.tw (J.-F.T.); hungnp30@fe.edu.vn (P.-H.N.)

2 Faculty of Business, FPT University, Hanoi 100000, Vietnam; lanthhs130007@fpt.edu.vn (H.-H.L.); tuannahs140730@fpt.edu.vn (A.-T.N.)

3 Department of Urban Industrial Management and Marketing, University of Taipei, Taipei 11153, Taiwan

4 Quantitative Analysis Center, QA Global Co., Hanoi 100000, Vietnam; duynguyen.qa@gmail.com

* Correspondence: mhlin@utaipei.edu.tw

check for

updates

Citation: Tsai, J.-F.; Nguyen, P.-H.; Lin, M.-H.; Nguyen, D.-V.; Lin, H.-H.; Ngo, A.-T. Impacts of Environmental Certificate and Pollution Abatement Equipment on SMEs' Performance: An Empirical Case in Vietnam. Sustainability 2021, 13, 9705. https:// doi.org/10.3390/su13179705

Academic Editors: Lasse Torkkeli and Susanne Durst

Received: 24 July 2021

Accepted: 25 August 2021

Published: 30 August 2021

Publisher's Note: MDPI stays neutral with regard to jurisdictional claims in published maps and institutional affiliations.

Copyright: (c) 2021 by the authors. Licensee MDPI, Basel, Switzerland. This article is an open access article distributed under the terms and conditions of the Creative Commons Attribution (CC BY) license (https:/ / creativecommons.org/licenses/by/ $4.0 /)$.

\begin{abstract}
Increasing global warming and intensity of disasters recently have made improving environmentally-conscious enterprises pivotal, as well as consumer demand for green products and the achievement of green strategies in some enterprises. This study explores the impact of environmental certificates and the cost of pollution abatement equipment on firm performance for small and medium-sized enterprises (SMEs). In this research, the linear regression method examines the effect of environmental-related certificates and technology on SMEs' performance using Stata version 14.0 software. The training dataset comprises 3504 manufacturing SMEs in Vietnam during 2011-2015. The results highlight the positively considerable impacts of environmental-related certificates and the cost of pollution abatement equipment on SMEs' performance. More importantly, the findings also highlight the excessive availability of pollution abatement equipment and whether it adversely impacts enterprises' performance. The equipment cost positively impacts firm performance while, at an extreme value, the result shows a negative correlation. Furthermore, this study enriches the current literature on corporate social responsibility (CSR) and suggests SMEs approach and embrace more environmental-related certificates and technology to increase productivity.
\end{abstract}

Keywords: environmental certificates; pollution abatement equipment; corporate social responsibility; firm performance; SMEs

\section{Introduction}

Vietnam has emerged as the fastest-growing industrial economy in the ASEAN region during the last three decades. Labor forces migrated rapidly from agriculture to manufacturing, resulting in substantial pay gains. Small and medium-sized enterprises (SMEs) are considered a critical research matter since they have functioned as a pivotal part of the sustainable growth of economies worldwide. It is undeniable that to contribute to economic growth, they have offered huge advantages like reducing poverty, generating employment opportunities, yielding innovations, diversifying, and increased competition. This study concentrates on SMEs in the manufacturing area, and the classification of SMEs will bear a striking resemblance with Vietnam's Enterprise Law definition. Following the Enterprise Law (Decree No. 39/2018/ND-CP), SMEs are segregated into three categories which are micro, small, and medium-sized firms. Micro-level firms have up to 10 employees, whereas small-level firms have up to 100, and medium-level firms have up to 200 [1]. Also, this classification is based on full-time, part-time, and casual employees.

However, SMEs are heterogeneous in resources, management style and personal relationships [2], constraining them to adapt to large firm practices. In addition, a critical 
difference between large and small firms is that in small firms, ownership and management are not separated to the same extent as they are in large multinational firms [3]. Therefore, according to the classification criteria from Table 1, the stipulations of the government in Decree No. 39/2018/ND-CP has also declared that the total capital and total revenue of a firm can also be the measurement of firm-size as such micro-sized firms have less than 3 billion in annual total revenue or less than 3 billion in total capital. Meanwhile, small-sized firms have no more than 50 billion in annual total revenue or no more than 20 in total capital, and medium-sized firms have less than 200 billion in annual total revenue or no more than 100 billion in total capital. These classifications by total revenue and total capital are estimated in VND.

Table 1. Classifications of Vietnamese small and medium-sized enterprises (SMEs).

\begin{tabular}{|c|c|c|c|c|c|c|}
\hline & \multicolumn{2}{|c|}{ Micro-Enterprises } & \multicolumn{2}{|c|}{ Small Enterprises } & \multicolumn{2}{|c|}{ Medium Enterprises } \\
\hline & $\begin{array}{l}\text { Number of } \\
\text { employees } \\
\text { (Person) }\end{array}$ & $\begin{array}{l}\text { Total capital and total } \\
\text { revenue } \\
\text { (VND billion) }\end{array}$ & $\begin{array}{l}\text { Number of } \\
\text { employees } \\
\text { (Person) }\end{array}$ & $\begin{array}{l}\text { Total capital and total } \\
\text { revenue } \\
\text { (VND billion) }\end{array}$ & $\begin{array}{l}\text { Number of } \\
\text { employees } \\
\text { (Person) }\end{array}$ & $\begin{array}{c}\text { Total capital and total } \\
\text { revenue } \\
\text { (VND billion) }\end{array}$ \\
\hline $\begin{array}{l}\text { Agriculture, } \\
\text { Forestry, Fisheries, } \\
\text { Industry and } \\
\text { Construction }\end{array}$ & $\begin{array}{l}\text { No more } \\
\text { than } 10\end{array}$ & $\begin{array}{c}\text { No more than } 3 \text { in } \\
\text { annual total revenue or } \\
\text { no more than } 3 \text { in total } \\
\text { capital }\end{array}$ & $\begin{array}{c}\text { From more } \\
\text { than } 10 \text { to } \\
100\end{array}$ & $\begin{array}{c}\text { No more than } 50 \text { in } \\
\text { annual total revenue } \\
\text { or no more than } 20 \text { in } \\
\text { total capital }\end{array}$ & $\begin{array}{l}\text { From more } \\
\text { than } 10 \text { to } 200\end{array}$ & $\begin{array}{l}\text { No more than } 200 \text { in } \\
\text { annual total revenue } \\
\text { or no more than } 100 \\
\text { in total capital }\end{array}$ \\
\hline Trade and service & $\begin{array}{l}\text { No more } \\
\text { than } 10\end{array}$ & $\begin{array}{c}\text { No more than } 10 \text { in } \\
\text { annual total revenue or } \\
\text { no more than } 3 \text { in total } \\
\text { capital }\end{array}$ & $\begin{array}{l}\text { From more } \\
\text { than } 10 \text { to } 50\end{array}$ & $\begin{array}{l}\text { No more than } 100 \text { in } \\
\text { annual total revenue } \\
\text { or no more than } 50 \text { in } \\
\text { total capital }\end{array}$ & $\begin{array}{l}\text { From more } \\
\text { than } 10 \text { to } 100\end{array}$ & $\begin{array}{l}\text { No more than } 300 \text { in } \\
\text { annual total revenue } \\
\text { or no more than } 100 \\
\text { in total capital }\end{array}$ \\
\hline
\end{tabular}

Source: The Authors' Compilation from Decree No 39/2018/ND-CP.

SMEs had played a crucial role in Vietnam's economic change since 1986 when the Doi Moi reform was launched [4]. Much research has revealed increased social awareness on environmental sustainability and firm performance during the last few decades, particularly concerning pollution abatement policy [5-7]. Previous studies denoted that environmental sustainability is considered as a competitive advantage in the market [8], boosting financial performance [9] and investment strategies for economic sustainability growth [10]. In contrast, many scholars agreed with the manager's perspective that environmental protection and firm financial performance are mutually exclusive due to the cost of handling pollution problems [11,12]. Economic researchers argued that environmental investment might impede the firm's ability to invest in other productive projects [13], operating flexibility may be restricted by pollution abatement requirements, leading to increased expenses [14]. Also, many environmental regulations incorporate additional incentives for investment in new, better efficiency infrastructure by increasing the manufacturing costs [15]. Recently, Nguyen et al. [16] investigated the share prices of the Vietnamese listed steel companies. Their findings also confirmed the close relationship between environmental factors and stock prices.

Based on the review of the most pertinent literature in the context of CSR perspectives, Meseguer-Sánchez et al. [17] identified three pillars of CSR: social, environmental, and economic-financial dimensions of CSR and sustainability. Several studies have devoted significant efforts to researching the effect of CSR on firm performance and CSR in assimilating firms' environmental strategies and the constant changes of the business environment [18-20]. However, this study will concentrate on certificates and investment for environmental-related equipment, contributing to CSR literature.

The effects of obtaining an environmental standard certificate (ESC) on SMEs' performance results have received less scrutiny. The firms must satisfy the requirements (i.e., technology, employment training, polluted abatement equipment) of the government policy to achieve environmental sustainability certification [21] due to the positive support from environmental-related certificates to the management system of the firm [22]. Significantly, the pollution abatement equipment is regarded as a crucial part of achieving ESC. 
Using pollution abatement equipment will increase productivity efficiency [23]. Henceforth, firms can jump at the chance to increase performance by the trends in environmental attention to the business [24], meeting the customer's requirements on quality [25], as well as communication instruments for brand reputation improvement [26].

Thus, it remains an absorbing empirical inquiry on how environmental certification and pollution abatement may impact the performance of SMEs. This research attempts to contribute gaps in the literature on how environmental protection impacts SMEs' performance in under-developed countries. We evaluate the effect of environmental-related certificates and the cost of pollution abatement equipment to consider how these factors may affect firm performance. This work focuses on testifying the implication of environmentally conscious SMEs behavior in Vietnam, showing an intriguing and unique context, and it is suitable for our empirical analysis for many reasons. First, Vietnam has grown stably since establishing the "Doi Moi" economic liberalization reform and further fostered economic growth by participating in World Trade Organization in 2007 [27]. Specifically, SMEs are the primary driver of Vietnam's economy since they make up approximately $95 \%$ of all companies, half of the total workforce, and roundly $40 \%$ of GDP [28].

Nevertheless, due to their size, solitude, limited resources, or complicated laws and processes, SMEs are commonly thought to have difficulty adopting CSR, particularly EMS. Second, the purposes of the registration of enterprises for an environmental management system (EMS) tool are to avoid the risk of breaching laws, accommodating customer demands, and utilizing that tool for potentially saving costs and making an improvement to environmental problems [29]. Third, EMS is recognized as a highly relevant and recommended key to mitigating adverse environmental effects by human activities and firm behavior [30]. Furthermore, with the noticeable revolution of the economy in Vietnam, environmental issues also arose more frequently [27]. Hence, the consequences of environmental degradation induce the development of green strategies, and business ventures of SMEs have to be integrated with EMS. In addition, previous researchers have demonstrated that firm performance was also affected sharply by stakeholders' pressure [31] when social and environmental responsibility and financial prosperity have steadily become principal goals for firms [32]. Also, developing an environmental strategy will involve strategic planning, along with cross-division coordination [33].

However, there is no evidence of a relationship between the cost of green equipment and the operation of firms. Therefore, this study appears uniquely to integrate environmental certificates and cost of pollution abatement equipment to examine how these factors affect firm performance is a critical research matter and a pivotal policy reform. The analytical results indicate several vital objectives as follows. The productivity of firm performance is improved when they apply their product more following the certifications. Besides, an increasing fund for equipping environmental-related technology will benefit firm performance. More intriguingly, even when the cost of investment for pollution abatement equipment becomes excessive, it seems not to affect firm performance at all.

The remainder of this study is arranged as follows. Section 2 presents the literature review. The training data and empirical methodology are described in Section 3. Next, Section 4 reports the main empirical results and discussion. Section 5 continually supports the paper with conclusions. Finally, Section 6 suggests some implications and limitations of this research.

\section{Literature Review and Hypothesis Development}

Stakeholder theories and institutional theories are two theories that could be used in this research. Stakeholder theories related to this study are shareholders strategy and socialharmony strategy [34]. Corporate social responsibility (CSR) is significant to shareholders' strategy since it promotes benefits in the long term for the owners [35]. While the socialharmony approach asserts that all stakeholders' expectations and interests must be matched, it does not isolate ethics from business [36]. In common parlance, social responsibility is a government problem; it does not belong to the firm's goals because the only significant 
purpose is to generate income [37]. The institutional theory attempts to help clarify and evaluate how an innovative system, for instance, investing in research and development and upgrading equipment for environment-friendly purposes, has been adopted. The key drivers of environmental management efforts were determined to be environmental regulation and political pressure [31,32]. In addition, firms are devoting a great deal of awareness to their core values and establishing a CSR approach $[38,39]$. Besides the motivation from competitors, customers, and workforce [40], other forces such as marketing advantage [41] and avoiding a possible impediment to export may influence environmental management and incentivize a firm to achieve an environmental certificate [34].

Literature on corporate environmental management seems modest and has centered mainly on adopting self-regulatory factors [26]. EMS was designed to illustrate causation between environmental certification and financial achievement and evaluate environmental performance across different business sectors [34]. Also, the environmental sustainability tactic is an instrument that may well enable businesses to obtain a competitive advantage and enhance their productivity [35-37]. In a similar vein, pollution is often linked with a waste of resources, raw materials which are not entirely utilized, or energy wasted. Supportively, pollution is a component of economic wastage that occurs when resources are used inefficiently or ineffectively, and pollution reduction frequently occurs in tandem with increased productivity in resource utilization [42,43]. Hence, environmental factors might motivate innovative products [44], and green technology might be a critical competitive motivator $[45,46]$.

The 2005 Law on Environmental Protection (LEP), the Decree 29/2011, and the circular 2781/TT-KCM have been controlled by national environmental standard certificates [47]. All Vietnamese firms are encouraged to and can obtain an ESC. To obtain an ESC from the Ministry of Natural Resources and Environment, an enterprise must demonstrate compliance with the pollution and environmental control measures it committed to through an environmental impact assessment (EIA). The LEP's Decree 29/2011 requires businesses that engage in certain polluting or environmentally hazardous activities to conduct a detailed environmental impact assessment and have it approved. Businesses can opt to have their environmental performance certified to obtain ESC. Additionally, enterprises in some industries, such as leather, must obtain an ESC under Circular 2781/TT-KCM.

The ESC is regarded as a firm's commitment to protecting the environment [48] since the policymaker enacted laws and regulations related to ecological issues [49]. Despite these legislative efforts, evidence suggests that ESCs have had limited success in Viet Nam. Their diffusion is still extremely limited in practice due to a low level of compliance, resulting from widespread ignorance about environmental regulations and a lack of enforcement [50].

In addition, low-polluting firms outperformed others in terms of productivity [51]. In particular, pollution abatement equipment is regarded as a crucial part of achieving ESC. Firms would take opportunities to increase performance by the trending environmental attention for the business [24], meeting the customer's requirements on quality [25], as well as communication instruments for brand reputation improvement [26]. Regarding the environmental responsibility of small and medium-sized enterprises, SMEs tend to develop environmental policies and management systems, hire specialized personnel, and communicate their values and objectives to their collaborators [52]. Henceforth, environmentalfriendly firms are increasingly preferred by customers, and many firms optimized their profit and cost by jumping at the chance to invest in eco-friendly initiatives [53].

In contracts, the effect of obtaining an ESC on SMEs' performance results has received less scrutiny. Environmental activities are expensive since they require substantial research technology to build green processes or products that reduce detrimental environmental consequences and comply with eco-efficiency criteria $[47,48]$. In addition, firms must satisfy the requirements (i.e., technology, employment training, polluted abatement equipment) of government policy to achieve environmental sustainability certification [54,55]. However, SMEs experienced insufficient expertise and instruments to execute green practices in production activities [56]. Moreover, SMEs believe that environmental protection is the 
duty of the regional administration and authorities instead of them [57]. This exemplifies the limitations for SMEs to sustainability development [58]. This research attempts to test our two hypotheses on our data collected based on the theories and literature. The framework of this research is indicated in Figure 1.

\section{Independent Variables}

Dependent Variables

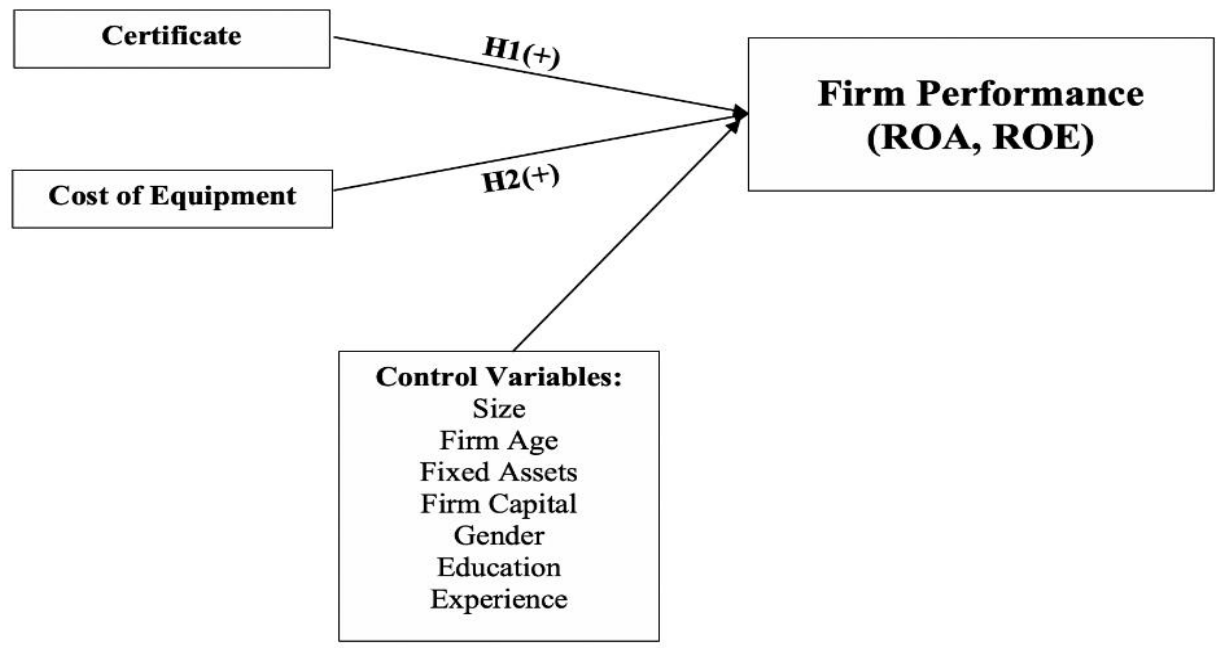

Figure 1. Research framework.

In Vietnam, for example, the policy for addressing environmental degradation by the manufacturing sector has been applied since 1999, indicated as Environmental Certificates or ISO 14001 by Vietnam's National Strategy for Environmental Protection in the period of 2010-2020 [59]. Applying environmental or ISO regulations offers benefits to SMEs, such as reducing waste management costs and decreasing the energy consumption or materials used. Also, following the studies of Casio [60], Marcus and Willig [61], Woodside [62], Cheremisinoff and Bendavid-Val [63], Morris [64], and Sheldon [65], certificated firms also surpassed others by the performance of firms since they had made more remarkable progress in enhancing firm-image, saving costs for regulation infringement, and improving stakeholder relationships [66]. We will propose the first hypothesis to examine how environmental certificates affect Vietnam's SMEs performance from the discussion above.

Hypothesis (H1). Environmental certificate has a positive impact on firm performance.

To accommodate the requirement of the government's environmental protection policies, SMEs may need to fortify the firm's technology, employment training, and environment-related equipment [67]. Pollution abatement equipment is regarded as a crucial part of achieving ESC. As mentioned earlier, the level of investment requirement might be relatively high. However, as in the study of Del Brío [21], despite the time and cost spent on satisfying environmental regulations, SMEs may gain more opportunities to obtain new market niches or even increase their firm performance efficiency from improving firm-image. Thus, the relationship between pollution abatement equipment will be assessed through the second hypothesis.

Hypothesis (H2). Investing in eco-friendly equipment has a positive impact on firm performance.

\section{Methodology and Data}

\subsection{Empirical Methodology}

This research aims to evaluate how the environmental certificates and pollution abatement equipment affect the firm performance. Specifically, we employ the linear regression specification, which effectively provides versatile controls to determine the coefficient even with many fixed effects. The regression model is described in the following: 


$$
\begin{aligned}
\text { Firm Performance }_{i}= & \beta_{0}+\beta_{1} \text { Certificate }_{i t}+\beta_{2} \text { Cost of Equipment }_{i t}+\beta_{3} \text { Size }_{i t} \\
& +\beta_{4} \text { FirmAge }_{i t}+\beta_{5} \text { Fixed Assets }_{i t}+\beta_{6} \text { Firm Capital }_{i t} \\
& +\beta_{7} \text { Gender }_{i t}+\beta_{8} \text { Education }_{i t}+\beta_{9} \text { Expericence }_{i t}+\text { Fixed Effects }+\mu_{i t}
\end{aligned}
$$

In Equation (1), $i$ is denoted as an individual firm, $t$ resembles year, $\mu_{i t}$ is the idiosyncratic error. Fixed effects (FEs, i.e., year fixed effect, sector fixed effect) are included in our empirical model, which takes into account all factors unchanged in four years and given sector and year (i.e., business cycle, local economic situation) [68]. We measure our dependent variable, performance, by employing the profitability ratio: return on equity (ROE) and return on assets (ROA) to represent the firm performance [69].

Our primary explanatory variables are certificate and cost of equipment. The certificate is a binary variable with the value of one if the firm has the ESC, zero otherwise. The cost of equipment is measured by the total expenses that the firm spends to buy equipment for tackling environment-related problems. All variables are described in Table 2.

Table 2. Variables definition.

\begin{tabular}{cc}
\hline Variables & Definition \\
\hline Performance & Source \\
Certificate & Return on Equity (ROE), Return on Assets (ROA) \\
Cost of Equipment & Total expenses the firm spends to buy equipment for tackling the environment-related problems \\
Size & Dn (Total Assets) \\
Firm Age & Sn (Years of operation since the firm's establishment +1$)$ \\
Fixed Assets & Firm's fixed assets divided by total assets \\
Firm Capital & Firm's equity divided by total assets \\
Gender & SMEs Surveys \\
Education & Dummy variables, one if the owner is male, zero otherwise \\
Experience & Dummy variables, one if the owner finished upper secondary school, zero otherwise \\
Sn (Number of years the owner taking over the company)
\end{tabular}

\subsubsection{Dependent Variable}

Performance is measured as the ratio of return on equity (ROE) and return on assets (ROA) to estimate the productivity and effectiveness of firm operation since the environmental problems had an intense relationship with sustainable development [70], as well as the importance of environmental propensity in manufacturing. Therefore, firm performance is highlighted to test the effect of environmental-related factors on SMEs.

\subsubsection{Independent Variables}

The certificate is denoted as a binary variable since not all firms applied certificates for accommodating environmental standards' satisfaction. The study of [71] devoted significant efforts to point out the benefit of applying environmental-related certificates in the firm's sustainable development. Following that, other studies also indicated the positive effect of the environment-related certificate on generating new products [72]. For this study, the certificate is considered, including all environment-related certificates.

Cost of equipment is the total expenses the firm spends to buy equipment for treating environment-related problems from 2011 to 2015 (Figure 2). In terms of the cost of equipment, Oxborrow [45] has proved a positive and significant effect of green technology on competitiveness, facilitating firm performance. In addition, the cost of equipment is considered a key to boosting the firm's profit [43].

\subsubsection{Control Variables}

This study incorporates control variables, including size, firm age, fixed assets, firm capital, gender, education, and experience. Size is measured as the natural logarithm of a firm's total assets. The size of a firm may impact its performance [71]. Firm age is measured as the natural logarithm of years of operation since the firm's establishment plus 
one. Besides, the age of an enterprise may affect performance due to its experiences and knowledge in the industry $[73,74]$.
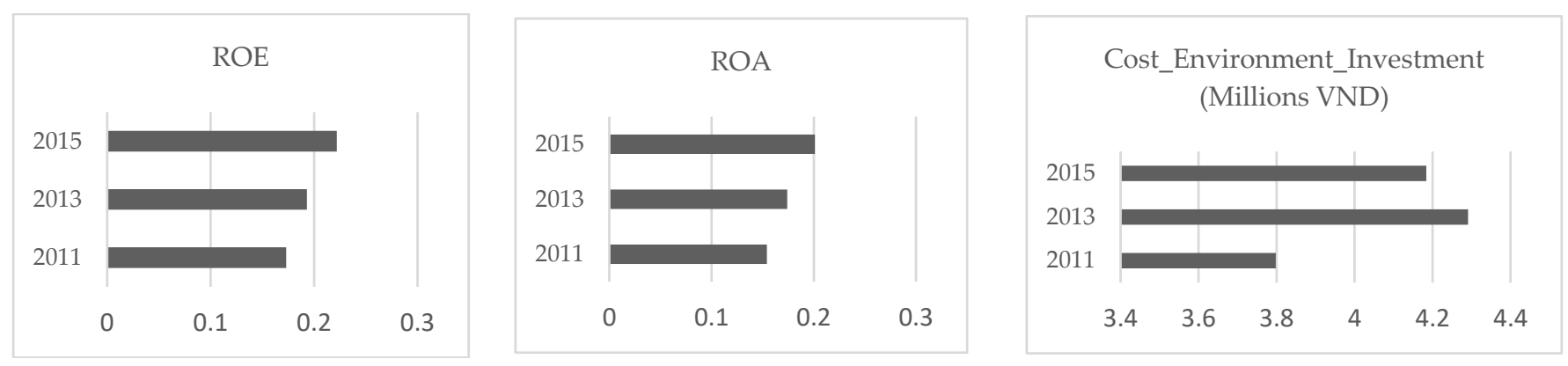

Figure 2. Mean value of ROA, ROE, and cost of equipment in the period 2011-2015.

Regarding firm assets' influence, fixed assets are measured as total fixed assets divided by total assets [75,76], while firm capital is defined as equity divided by total assets [77]. Alternatively, the gender of the owner is considered to affect the performance of the firm [78]. Gender is measured as a dummy variable, one if the owner is male and zero otherwise [79]. It is documented that performance may be significantly enhanced by applying the owner's knowledge and experience [80]. Thus, the owner's education may have an impact on performance and is measured as a dummy variable, one if the respondent finished upper secondary school, zero otherwise. Also, the experience of a manager may be associated with firm performance [81]. Experience is measured as the natural logarithm of the number of years the owner has run the company.

\subsection{Data Description}

The data are extracted from the surveys of the Vietnamese SMEs in the period from 2005 to 2015. The surveys were conducted by the Central Institute for Economic Management of the United Nations University, collaborating with the Development Economics Research Group and the World Institute for Development Economics Research (UNUWIDER). The sample size of non-state manufacturing firms in nine provinces was chosen to utilize two sources of data from Vietnam's General Statistics Office (GSO) [82] and the Industrial Census [83]. The number of respondents remained at approximately 2600 firms each year from 2005 to 2015, with the replacement of firms exiting the survey by new firms [47]. The surveys consisted of three rounds: (1) the main questionnaires were responded to by owners or managers; (2) questions about employees; and (3) economic accounts. Our research mainly concentrates on rounds (1) and (3) giving specific company information. With this data source from UNU-WIDER, we acquired and used exclusive and comprehensive panel data depicting firm characteristics from UNU-WIDER to shed light on the impact of environmental certificates and pollution abatement equipment on SMEs' diversification.

Most SMEs were concentrated in Ha Noi City (2630) and Ho Chi Minh City (3682), Vietnam's two biggest cities, while only 111 firms were located in Quang Nam. The rest were spread across the remaining seven provinces in the country's three regions. The locations of those Vietnamese firms considered in this study are illustrated in Figure 3.

When processing data, observation of missing values and unreliable answers were missing. Firstly, companies with just 10-500 workers were classified by the White Paper as SMEs: Vietnamese small and medium enterprises [84]. Secondly, firms' equities below 0 were eliminated, and ROE equal or above 1 of fixed assets/total assets was omitted. Finally, independent variables were winsorized at the 1st and 99th percentiles to avoid the effects of drastic variables [4]. This study attempts to access the most updated data until 2020; however, the SMEs survey results have not been launched by GSO since 2015. The training data are from 3504 firms in the 2011-2015 period identified by this study based on the consistency of surveyed questions and answers. The size of sample companies is presented 
in Table 3. In this study, firm size is measured by the natural logarithm of total assets and divided into three classifications: Micro, Small and Medium.

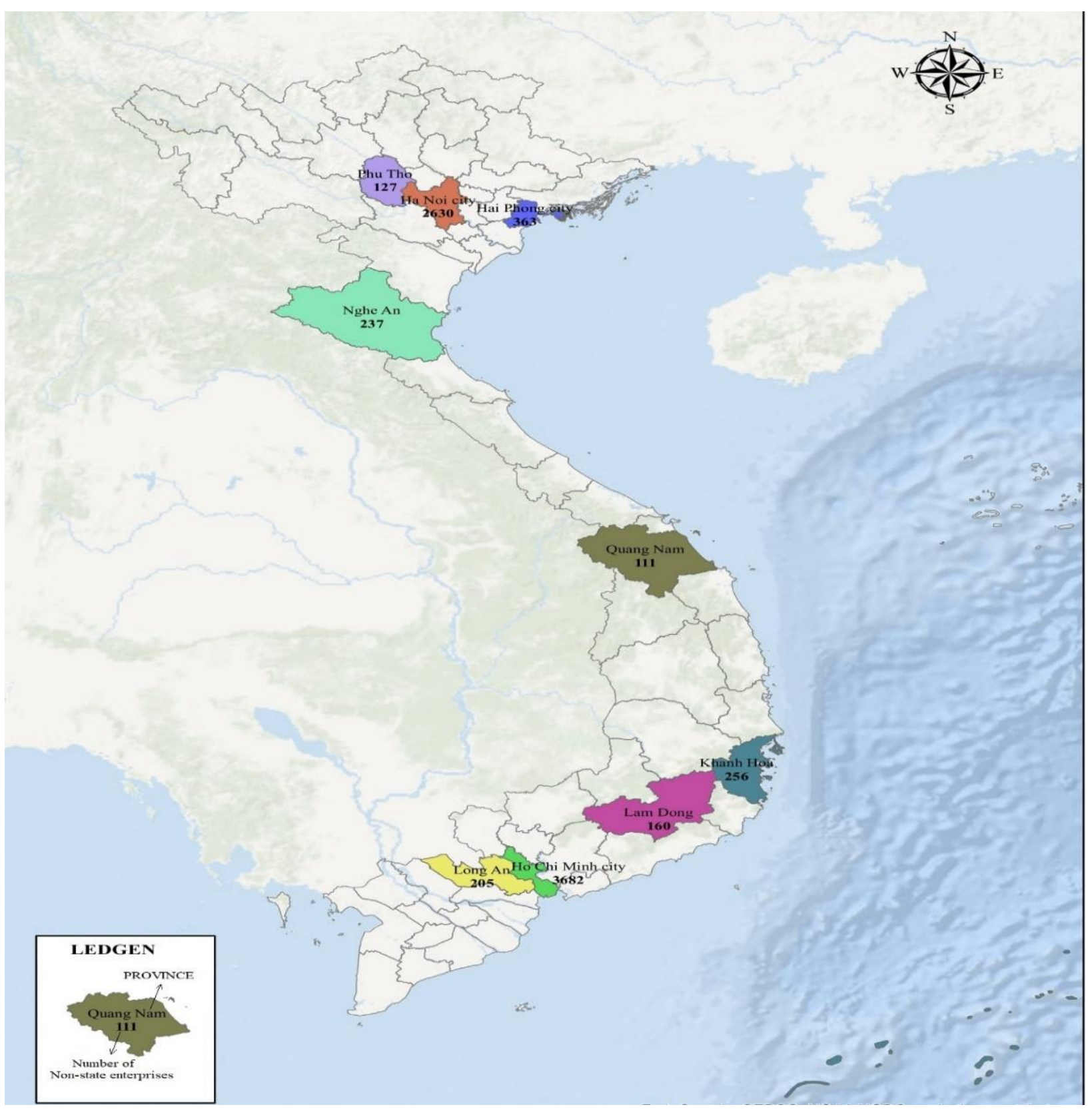

Figure 3. Locations of the Vietnamese firms considered in this study.

Table 3. Classifications of size of the sample companies.

\begin{tabular}{cccc}
\hline Firm Size & $\mathbf{2 0 1 1}$ & $\mathbf{2 0 1 3}$ & $\mathbf{2 0 1 5}$ \\
\hline Micro & 535 & 596 & 680 \\
Small & 604 & 607 & 596 \\
Medium & 1248 & 1192 & 1177 \\
Total & 2387 & 2395 & 2453 \\
\hline
\end{tabular}

\section{Empirical Results}

This research conducts tests, including descriptive statistics, correlation analysis, and linear regressions, by employing Stata version 14.0 software. 


\subsection{Descriptive Statistic}

Table 4 summarizes the firm-level data from our empirical investigation. According to the data set results, the firm's profits divided by equity and asset are relatively low, averaging $19.7 \%$ and $17.7 \%$, respectively. These results indicate that the performance of SMEs has not been effective yet. In terms of certified firms, only $15.4 \%$ of firms willing to put their business under control means SMEs tend to be less like certified firms or products. Most firms do not consider the investment in pollution abatement equipment which accounted for only a little more than $4 \%$ of total firms. As in SMEs, fixed assets accounted for the vast majority of the firm's value, a mean of 0.779 .

Table 4. Results of descriptive statistics.

\begin{tabular}{lccccc}
\hline & Mean & SD & p25 & p50 & p75 \\
\hline ROE & 0.197 & 0.201 & 0.049 & 0.121 & 0.280 \\
ROA & 0.177 & 0.177 & 0.047 & 0.113 & 0.250 \\
Certificate (dummy) & 0.154 & 0.361 & 0 & 0 & 0 \\
Cost of Equipment (Millions VND) & 4.093 & 4.441 & 0 & 0 & 8.305 \\
Size (ln) & 14.239 & 1.430 & 13.164 & 14.300 & 15.315 \\
Firm Age (year) & 2.581 & 0.549 & 2.197 & 2.639 & 2.996 \\
Fixed Assets (ln) & 0.783 & 0.187 & 0.681 & 0.845 & 0.932 \\
Firm Capital & 0.944 & 0.103 & 0.938 & 1 & 1 \\
Gender (dummy) & 0.606 & 0.488 & 0 & 1 & 1 \\
Education (dummy) & 0.687 & 0.464 & 0 & 1 & 1 \\
Experience (ln) & 13.008 & 6.980 & 8 & 12 & 18 \\
Observations & 7701 & 7701 & 7701 & 7701 & 7701 \\
\hline
\end{tabular}

\subsection{Correlation Analysis}

In this section, this study presents the Pearson's correlation between variables used in our analysis to investigate the relationship between an environmental certificate, pollution abatement, and firm performance (ROA, ROE, certificate, cost of equipment, size, firm age, fixed assets, firm capital, gender).

Table 5 lists the correlation matrix between variables used in our analysis. In general, most productive SMEs which optimize their profits better than others may seem to possess pollution abatement equipment for their firms due to the coefficient of cost of equipment $-0.043(p<0.01)$. The correlation matrix indicates that better firm performance is associated with more products and firms being certified because the certificate coefficient is $0.309(p<0.01)$. The firm's performance is improved by increasing firm capital by 0.156 $(p<0.01)$ in the correlation matrix result. In addition, when SMEs pursue the investment for environmental-related technology in parallel, expanding the firm's scale induces less effective performance. Regarding other pairs, most of the correlation coefficients are lower than 0.4 . The highest level of correlation is 0.862 between gender and cost of equipment.

Table 5. Results of correlation analysis.

\begin{tabular}{ccccccccc}
\hline Variables & $\mathbf{1}$ & $\mathbf{2}$ & $\mathbf{3}$ & $\mathbf{4}$ & $\mathbf{5}$ & $\mathbf{6}$ & $\mathbf{7}$ & $\mathbf{8}$ \\
\hline ROE & 1.000 & & & & & & & \\
ROA & $0.305^{* * *}$ & 1.000 & & & & & \\
Certificate & $0.309^{* * *}$ & $0.435^{* * *}$ & 1.000 & & & & \\
Cost of Equipment & $-0.043^{* * *}$ & $-0.151^{* * *}$ & $-0.161^{* * *}$ & 1.000 & & & \\
Size & $-0.094^{* * *}$ & $-0.098^{* * *}$ & $0.052^{* * *}$ & $0.127^{* * *}$ & 1.000 & & \\
Firm Age & $-0.098^{* * *}$ & $-0.067^{* * *}$ & $-0.061^{* * *}$ & $0.076^{* * *}$ & $0.298^{* * *}$ & 1.000 & & \\
Fixed Assets & $-0.101^{* * *}$ & $-0.106^{* * *}$ & $-0.078^{* * *}$ & $0.043^{* * *}$ & $0.029^{* *}$ & 0.015 & 1.000 & 1.000 \\
Firm Capital & $0.156^{* * *}$ & $0.259^{* * *}$ & $0.259^{* * *}$ & $-0.155^{* * *}$ & $-0.172^{* * *}$ & $-0.109^{* * *}$ & -0.012 & $1.009^{* * *}$ \\
Gender & $-0.079^{* * *}$ & $-0.158^{* * *}$ & $-0.198^{* * *}$ & $0.862^{* * *}$ & $0.141^{* * *}$ & $0.089^{* * *}$ & $0.069^{* * *}$ & 1.000 \\
\hline
\end{tabular}

${ }^{* * *} p<0.01,{ }^{* *} p<0.05, * p<0.1$ 


\subsection{Regression Analysis}

In this study, linear regression analysis was deployed to examine the correlation between an environmental certificate, pollution abatement, and firm performance.

A defect in heteroskedasticity often occurs with the fixed effects model (FEM), commonly used in panel data analysis. The cluster correction method is implemented to overcome the errors that occur due to the characteristics between firms. This study performs the analysis based on the cluster correction method on the FEM model. Table 6 presents the primary model results to examine the effects of environmental-related certificates, environmental-related investment cost, and control variables on firm performance. Column (1) testifies to the relationship between ROE and environmental-related certificates and the cost of pollution abatement investment, whereas the effects on ROA are shown in column (2).

Table 6. Impact of environmental certificate and pollution abatement on firm performance.

\begin{tabular}{ccc}
\hline & $\mathbf{( 1 )}$ & $\mathbf{( 2 )}$ \\
\hline Variables & ROE & ROA \\
\hline Certificate & $0.024^{* * *}$ & $0.022^{* * *}$ \\
& $(0.007)$ & $(0.006)$ \\
Cost of Equipment & $3.201^{* * *}$ & $2.725^{* * *}$ \\
Size & $(0.667)$ & $(0.606)$ \\
& $-0.071^{* * *}$ & $-0.065^{* * *}$ \\
Firm Age & $(0.002)$ & $(0.002)$ \\
& -0.010 & -0.006 \\
Fixed Assets & $(0.008)$ & $(0.007)$ \\
& $-0.256^{* * *}$ & $-0.237^{* * *}$ \\
Firm Capital & $(0.016)$ & $(0.014)$ \\
Gender & $-0.187^{* * *}$ & 0.006 \\
& $(0.029)$ & $(0.024)$ \\
Education & -0.003 & -0.002 \\
& $(0.005)$ & $(0.004)$ \\
Experience & 0.002 & 0.003 \\
& $(0.005)$ & $(0.005)$ \\
Constant & -0.000 & -0.000 \\
& $(0.001)$ & $(0.001)$ \\
Year FEs & $1.564^{* * *}$ & $1.238^{* * *}$ \\
Industry FEs & $(0.096)$ & $(0.084)$ \\
R-square & Yes & Yes \\
Observations & Yes & Yes \\
Number of Firms & 0.37 & 0.36 \\
\hline Robust standard errors in parentheses. ${ }^{* * *} p<0.011^{* *} p<0.05, *<0.1$. & 5527 \\
& 5558 & 2898 \\
\hline & 2906 &
\end{tabular}

The coefficients between the effect of the certificate on two different firms' performance measurements are significantly positive, 0.024 and $0.022(p<0.01)$. This result supports hypothesis 1 and reveals that firms should gain as many environment-related certificates as possible to enhance performance by generating competitive advantage and productivity [35-37]. Alternatively, environmental certificates encourage firms to accommodate government assistance in policies and regulations that may reduce the expenses if the firm breaches any environmental-related investments [67]. Regarding the effect of pollution abatement investment on performance, the findings are consistent with hypothesis 2 . The outcome points out that environmental-related investment expenditures sharply impact performance, with positive coefficients in both two columns $(3.201$ and $2.725(p<0.01))$. It is argued that environmental-related technology played an essential role in the competition between firms [45].

Furthermore, pollution abatement equipment may reduce the waste of resources and make firms more careful about utilizing sources and replacing outdated equipment with 
new, more effective models in mitigating energy consumption [85]. Hence, our results indicate that productive (outstanding performance) firms tend to have an appropriate strategy for funding the investment in environment-related technology. Concerning the managerial perspective, managers must concentrate on CSR initiatives to provide satisfaction, trust, and support for various stakeholders, enabling firms to obtain additional capabilities and improve firm performance.

To strengthen this notion, it is crucial to emphasize that business owners have a variety of reasons for using EMS. As mentioned in the study of [59], most firms in Hochiminh and Hanoi city holder environmental certificates that comply with the environment law.

In terms of fixed assets, its coefficient negatively affects all testing with -0.256 and -0.237 . One possible explanation for this is that fixed assets are what the firms invested for the primary operation or manufacturing when they grew and accommodated for the benefit of certifications and environment-related equipment on firm performance. This will require them to replace a large number of inappropriate assets to follow the condition and regulations. By that, initially, the expenses for those categories will directly affect the firm's revenue, which will decrease the production of the operation and performance. Similarly, a more significant firm size requires the expansion of each product line [86]. Therefore, the investment in improving the environment from firms will be constrained, or if they are conducted in parallel to enlarging the firm and investing in environmental ventures, the performance effectiveness will be sharply reduced.

\subsection{Inverted U-Shaped Relationship between Investment Scales and Firm Performance}

As regards the price of new technology for diminishing emissions, waste, and reducing energy use $[83,86]$, this research further conducts an inverted U-shaped relationship between the cost of pollution abatement equipment and firm performance, which is reported in Table 7. Column (1) presents the effects on return on equity while column (2) presents the coefficient of the impact on return on assets (ROA), both by squared environmental-related investment costs. We discover the excessive investment in pollution abatement leads to an inverted U-shaped association with firm performance after employing a non-linearity test. The cost of green equipment is positively related to its performance. Utilizing a reasonable degree of pollution abatement investment will enable enterprises to boost their performance. Nevertheless, when SMEs overspend on green equipment, it becomes a performance discount issue with the value of -20.259 and -51.656 for ROE and ROA, respectively. The non-linearity results are displayed in Table 7.

The significant positive effects of the certificates on firm performance are consistent with our primary model's result, at 0.024 and $0.022(p<0.01)$. This finding points out moderate level in certification will bolster the firm's advantages in competition with other firms and increase the productivity in firm performance [35-37]. Also, the positive effects of a moderate cost of equipment on firm performance are obtained at 3.518 and 3.529 $(p<0.05)$. These results indicate that firms with higher investment in environmentalrelated technology will better perform in their firms. However, it seems to be no inverted U-shape effect where excessive investment for pollution abatement equipment happened.

No significant effect exists in the adverse impact of the cost of equipment on firm performance. Therefore, for further consideration, Table 8 shows the results of the effect of certificate and cost of equipment on firm performance by each scale of investment, as it seems that the effect of level of investment for the cost of equipment on firm performance by SMEs is very different. Columns (1) and (2) represent the measurement of ROE with a small investment and a significant investment, respectively. Also, columns (3) and (4) are the measurement of ROA with a small investment and a considerable investment, respectively. 
Table 7. Impact of environmental certificate and pollution abatement on firm performance: non-linear.

\begin{tabular}{ccc}
\hline & $\mathbf{( 1 )}$ & $\mathbf{( 2 )}$ \\
\hline Variables & ROE & ROA \\
\hline Certificate & $0.024^{* * *}$ & $0.022^{* * *}$ \\
& $(0.007)$ & $(0.006)$ \\
Cost of Equipment & $3.518^{* *}$ & $3.529^{* * *}$ \\
Size & $(1.580)$ & $(1.448)$ \\
& $-0.072^{* * *}$ & $-0.065^{* * *}$ \\
Firm Age & $(0.002)$ & $(0.002)$ \\
& -0.010 & -0.006 \\
Fixed Assets & $(0.008)$ & $(0.007)$ \\
Firm Capital & $-0.256^{* * *}$ & $-0.237^{* * *}$ \\
& $(0.016)$ & $(0.014)$ \\
Gender & $-0.187^{* * *}$ & 0.007 \\
& $(0.029)$ & $(0.024)$ \\
Education & -0.003 & -0.001 \\
& $(0.005)$ & $(0.004)$ \\
Experience & 0.002 & 0.002 \\
& $(0.005)$ & $(0.005)$ \\
Constant & -0.000 & -0.000 \\
& $(0.001)$ & $(0.001)$ \\
Year FEs & $1.563^{* * *}$ & $1.237^{* * *}$ \\
Industry FEs & $(0.096)$ & $(0.085)$ \\
R-square & Yes & Yes \\
Observations & Yes & Yes \\
Number of Firms & 0.37 & 0.36 \\
& 5558 & 5527 \\
& 2906 & 2898 \\
\hline
\end{tabular}

Robust standard errors in parentheses. ${ }^{* * *} p<0.01,{ }^{* *} p<0.05,{ }^{*} p<0.1$.

Table 8. Impact of environmental certificate and pollution abatement on firm performance: the size of investment.

\begin{tabular}{|c|c|c|c|c|}
\hline & \multicolumn{2}{|c|}{ ROE } & \multicolumn{2}{|c|}{ ROA } \\
\hline & (1) & (2) & (3) & (4) \\
\hline Variables & Small Investment & Large Investment & Small Investment & Large Investment \\
\hline \multirow[t]{2}{*}{ Certificate } & $0.015 *$ & $0.043^{* * *}$ & $0.012 *$ & $0.040 * * *$ \\
\hline & $(0.008)$ & $(0.014)$ & $(0.007)$ & $(0.013)$ \\
\hline \multirow[t]{2}{*}{ Cost of Equipment } & $8.863 *$ & $3.685^{* * *}$ & $8.525 *$ & $2.749 * * *$ \\
\hline & $(4.933)$ & $(1.044)$ & $(4.456)$ & $(0.976)$ \\
\hline \multirow[t]{2}{*}{ Size } & $-0.070^{* * *}$ & $-0.076^{* * *}$ & $-0.064^{* * *}$ & $-0.068^{* * *}$ \\
\hline & $(0.002)$ & $(0.005)$ & $(0.002)$ & $(0.004)$ \\
\hline \multirow{2}{*}{ Firm Age } & -0.010 & -0.009 & -0.008 & -0.002 \\
\hline & $(0.008)$ & $(0.020)$ & $(0.007)$ & $(0.019)$ \\
\hline \multirow[t]{2}{*}{ Fixed Assets } & $-0.271^{* * *}$ & $-0.249^{* * *}$ & $-0.246^{* * *}$ & $-0.243^{* * *}$ \\
\hline & $(0.019)$ & $(0.030)$ & $(0.017)$ & $(0.028)$ \\
\hline \multirow[t]{2}{*}{ Firm Capital } & $-0.187^{* * *}$ & $-0.192^{* * *}$ & -0.013 & 0.043 \\
\hline & $(0.032)$ & $(0.056)$ & $(0.027)$ & $(0.047)$ \\
\hline \multirow[t]{2}{*}{ Gender } & 0.001 & -0.013 & 0.001 & -0.007 \\
\hline & $(0.005)$ & $(0.011)$ & $(0.005)$ & $(0.010)$ \\
\hline \multirow{2}{*}{ Education } & 0.001 & 0.015 & 0.001 & 0.015 \\
\hline & $(0.005)$ & $(0.013)$ & $(0.005)$ & $(0.012)$ \\
\hline \multirow[t]{2}{*}{ Experience } & -0.000 & -0.000 & 0.000 & -0.001 \\
\hline & $(0.001)$ & $(0.002)$ & $(0.001)$ & $(0.001)$ \\
\hline \multirow[t]{2}{*}{ Constant } & $1.649^{* * *}$ & $1.502 * * *$ & $1.324 * * *$ & $1.138^{* * *}$ \\
\hline & $(0.044)$ & $(0.177)$ & $(0.041)$ & $(0.161)$ \\
\hline Year FEs & Yes & Yes & Yes & Yes \\
\hline Industry FEs & Yes & Yes & Yes & Yes \\
\hline R-square & 0.38 & 0.33 & 0.38 & 0.32 \\
\hline Observations & 4399 & 1159 & 4371 & 1156 \\
\hline Number of Firms & 2551 & 962 & 2538 & 963 \\
\hline
\end{tabular}

Robust standard errors in parentheses. ${ }^{* * *} p<0.01,{ }^{* *} p<0.05,{ }^{*} p<0.1$.

Table 8 shows the coefficients between the effect of the certificate and ROE in small investment and large investment levels, respectively, are $0.015(p<0.1)$ and $0.043(p<0.01)$, which are positively significant. Also, the coefficients between the effect of certificate and ROA in small investment and large investment levels, respectively, are $0.012(p<0.1)$ 
and $0.040(p<0.01)$. The results denote the differences between small investments and significant investments in supplementing related certificates. With a small investment, certificates somehow still positively affect the firm's performance (including ROE and ROA); however, they will significantly impact when the firms employ the significant investment. Simultaneously, the efficiency on the cost of equipment also shows the same meaning-in ROE the results of coefficients for small investment and large investment levels are $8.863(p<0.1)$ and $3.685(p<0.01)$, and in ROA they are $8.525(p<0.1)$ and 2.749 $(p<0.01)$. With a significant amount of funds, the cost of equipment will positively affect the firm operation. The evidence in the literature also supports this finding; the firm's size and scope of operations are viewed as critical variables impacting a firm's ability to absorb the initial cost of certification [87-92].

As Jawahar and McLaughlin [93] demonstrated, social response programs benefit businesses by improving their brand image and reputation while avoiding future oppressive government laws. In comparison, other research suggests that organizations that do not invest in CSR may experience resource misallocation and a drop in profit [94]. In terms of certificates, CSR includes many activities relating to the response of firms to the community. Therefore, certificates function as a crucial part of CSR in this research since certificated firms are supposed to need to accommodate the requirement in adapting government environmental regulations, namely to fortify technology, employment training, and investment for pollution abatement equipment [94].

Regarding previous findings [60-65], certificated firms may gain more benefits from better firm image, lower regulation-related costs, and the upside from better stakeholder relationships. Moreover, applying environmental or ISO certifications brings SMEs a lot of advantages, namely reducing costs as well as mitigating energy and materials use. Again, in this research, certificates will represent the contribution to the literature of CSR; also from this perspective, the positive and significant effect of certificates on firm performance have been proved by this study's findings.

\section{Conclusions}

Manufacturing SMEs contribute significantly to employment and income generation in Vietnam and are critical drivers of the overall economy's industrialization and modernization plan. In an era seeking high-quality growth and the Sustainable Development Goals (SDGs), product and process innovations directly contribute to organizations' sustainability by enabling them to maintain a competitive edge in increasingly competitive global and regional marketplaces. However, they focused on one area, one kind of certificate or type of company, to evaluate the effects of the environment. Therefore, this study concentrates on improving the environmental consciousness of enterprises and the advantage of approaching environmental factors for firm performance. Furthermore, this study is unique because we highlight a general view of environmental-related factors on SMEs in Vietnam.

From the results of this empirical analysis, which utilized the data of the SME surveys from 2011, 2013, and 2015 with the regression model, certified and equipped pollution abatement instruments, enterprises seems to gain more in both terms of small investment or significant investment, which means certificates and cost of environmental investment appear to have significant positive impacts on the effectiveness of the firm operation. The purposes of certified and equipped environment-related technology are beneficial to solid competitive ability, satisfying government policies, and exploiting resources better. Those factors may improve firm performance, make their products more reliable, and avoid the risk of breaching environmental regulation.

Furthermore, this finding also points out that when enterprises decide to increase the value of fixed assets or firm capital and the green application, it will generally decrease the effectiveness of firm performance. In addition, firm size needs to be considered a secondary proposal when the firm is conducting certification and erecting environmental support technology to secure the firm's performance. 
To sum up, this research examined the effectiveness of various environmental measures on the SMEs' performance might serve as a relevant case study for countries pursuing manufacturing-led development. Public awareness about environmental degradation and the demand for ecologically friendly products have propelled EMS certificates in Vietnam.

This study exemplifies that enterprises in developing countries might use EMS certificates to promote green products in developed countries. The high cost of adopting an EMS and a scarcity of enterprise awareness about the benefits of certification point to the need for additional government financial and technical assistance to encourage SMEs to embrace EMS certificates.

\section{Implications and Limitations}

This study suggests some practical implications:

1. SMEs should improve their ability to make their products certified and possess more environment-related technology to accommodate greater performance and government policy.

2. More importantly, getting a firm certified will broaden the benefit for owners in the long term, helping firms avoid business problems.

3. In addition, enlarging the size of the firm or fixed assets will be considered a secondary plan for developing firms when they decide to accommodate a "green" project; this, thereby ensuring the effectiveness of the "green" policy on firm performance.

Some limitations are also mentioned in this study:

1. The scope of this research is only conducted on SMEs in Vietnam and may not apply to other countries or market situations; therefore, the variance in the results may be significant and require retesting.

2. The results of this study are based on the aggregate of certificates and funds for environment-related investments and may not accurately reflect the effect of specific conditions, such as new certificates or a different investment strategy.

3. Additionally, the empirical analysis results are based on 3504 SMEs in Vietnam; hence, with a larger firm size or other significant small and medium businesses, pollution abatement equipment and certificates will have a different effect on a firm's performance.

4. Finally, we are unable to evaluate resource savings before and after the SMEs adopt and gain certificates. Another idea for future research is to study the application of environmental performance indicators in SMEs with an EMS.

Author Contributions: Conceptualization, P.-H.N. and D.-V.N.; methodology, P.-H.N. and D.-V.N.; software, A.-T.N.; validation, D.-V.N. and A.-T.N.; formal analysis, A.-T.N. and H.-H.L.; investigation, P.-H.N. and D.-V.N.; resources, A.-T.N. and H.-H.L.; data curation, P.-H.N.; writing-original draft preparation, P.-H.N.; writing—review and editing, J.-F.T. and M.-H.L.; visualization, H.-H.L.; supervision, J.-F.T. and M.-H.L.; project administration, J.-F.T. and M.-H.L.; funding acquisition, J.-F.T. and M.-H.L. All authors have read and agreed to the published version of the manuscript.

Funding: This research was supported in part by the Ministry of Science and Technology in Taiwan under Grant MOST 109-2410-H-027-012-MY2.

Institutional Review Board Statement: Not applicable.

Informed Consent Statement: Not applicable.

Data Availability Statement: Not applicable.

Acknowledgments: We thank the anonymous reviewers for their insightful suggestions and recommendations, which led to the paper's improvements in presentation and content.

Conflicts of Interest: The authors declare no conflict of interest. 


\section{References}

1. Decree No. 39/2018/ND-CP Dated March 11, 2018 on Guidelines for Law on Support for Small and Medium-Sized Enterprises. 2018. Available online: https:/ / hethongphapluat.com/decree-no-39-2018-nd-cp-dated-march-11-2018-on-guidelines-for-lawon-support-for-small-and-medium-sized-enterprises.html (accessed on 15 July 2021).

2. Jenkins, H. A critique of conventional CSR theory: An SME perspective. J. Gen. Manag. 2004, 29, 37-57. [CrossRef]

3. Spence, L.J.; Jeurissen, R.; Rutherfoord, R. Small business and the environment in the UK and the Netherlands: Toward stakeholder cooperation. Bus. Ethics Q. 2000, 10, 945-965. [CrossRef]

4. Rand, J.; Tarp, F. Micro, Small, and Medium Enterprises in Vietnam; Oxford University Press: Oxford, UK, 2020 ; pp. 30-51.

5. Shehu, A.M.; Mahmood, R. Influence of Entrepreneurial Orientation and Business Environment on Small and Medium Firm Performance: A PLS Approach. Adv. Manag. Appl. Econ. 2014, 4, 101-114.

6. Hart, S.L.; Ahuja, G.; Arbor, A. Does it pay to be green? An empirical examination of the relationship between emission reduction and firm performance. Bus. Strategy Environ. 1996, 5, 30-37. [CrossRef]

7. Taghizadeh-hesary, F.; Yoshino, N. The way to induce private participation in green finance and investment. Financ. Res. Lett. 2019, 31, 98-103. [CrossRef]

8. Henriques, I.; Sadorsky, P. The relationship between environmental commitment and managerial perceptions of stakeholder importance. Acad. Manag. J. 1999, 42, 87-99.

9. De Burgos-Jiménez, J.; Vázquez-Brust, D.; Plaza-Úbeda, J.A.; Dijkshoorn, J. Environmental protection and financial performance: An empirical analysis in Wales. Int. J. Oper. Prod. Manag. 2013, 33, 981-1018. [CrossRef]

10. D'Amato, D.; Droste, N.; Allen, B.; Kettunen, M.; Lähtinen, K.; Korhonen, J.; Leskinen, P.; Matthies, B.D.; Toppinen, A. Green, circular, bio economy: A comparative analysis of sustainability avenues. J. Clean. Prod. 2017, 168, 716-734. [CrossRef]

11. Cordeiro, J.J.; Sarkis, J. Proactivism and firm performance: Evidence from security analyst earnings forecasts. Bus. Strategy Environ. 1997, 6, 104-114. [CrossRef]

12. Thornton, D.; Kagan, R.A.; Gunningham, N. Sources of Corporate Environmental Performance. Calif. Manag. Rev. 2003, 46, 127-141. [CrossRef]

13. Rose, A. Modeling the macroeconomic impact of air pollution abatement. J. Reg. Sci. 1983, 23, 441-459. [CrossRef]

14. Joshi, S.; Lave, L.; Shih, J.S.; McMichael, F. Impact of Environmental Regulations on the US Steel Industry; Carnegie Mellow University: Pittsburgh, PA, USA, 1997.

15. Nelson, R.A.; Tietenberg, T.; Donihue, M.R. Differential environmental regulation: Effects on electric utility capital turnover and emissions. Rev. Econ. Stat. 1993, 75, 368-373. [CrossRef]

16. Nguyen, P.H.; Nguyen, P.H.; Tsai, J.F.; Nguyen, T.T.; Ho, V.N.; Dao, T.K. Determinants of Share Prices of Listed Companies Operating in the Steel Industry: An Empirical Case from Vietnam. J. Asian Financ. Econ. Bus. 2020, 7, 131-138. [CrossRef]

17. Meseguer-Sánchez, V.; Gálvez-Sánchez, F.J.; López-Martínez, G.; Molina-Moreno, V. Corporate social responsibility and sustainability. A bibliometric analysis of their interrelations. Sustainability 2021, 13, 1636. [CrossRef]

18. Svensson, G.; Ferro, C.; Høgevold, N.; Padin, C.; Varela, J.C.S.; Sarstedt, M. Framing the triple bottom line approach: Direct and mediation effects between economic, social and environmental elements. J. Clean. Prod. 2018, 197, 972-991. [CrossRef]

19. Ikram, M.; Zhou, P.; Shah, S.A.A.; Liu, G.Q. Do environmental management systems help improve corporate sustainable development? Evidence from manufacturing companies in Pakistan. J. Clean. Prod. 2019, 226, 628-641. [CrossRef]

20. Nguyen, H.T.; Hoang, T.G.; Luu, H. Corporate social responsibility in Vietnam: Opportunities and innovation experienced by multinational corporation subsidiaries. Soc. Responsib. J. 2020, 6, 771-792. [CrossRef]

21. Del Brío, J.Á.; Junquera, B. Influence of the perception of the external environmental pressures on obtaining the ISO 14001 standard in Spanish industrial companies. Int. J. Prod. Res. 2003, 41, 337-348. [CrossRef]

22. Tung, N.C.; Tung, N.C. determinants of a firm's iso 14001 certification: An empirical study of taiwan. Pac. Econ. Rev. 2007, 12, 467-487. [CrossRef]

23. Pargal, S.; Wheeler, D.; Bank, T.W.; Dc, W. Determinants of Pollution Abatement in Developing Countries: Evidence from South and Southeast Asia. World Dev. 1996, 24, 1891-1904.

24. Schaltegger, S.; Synnestvedt, T. The link between 'green' and economic success: Environmental management as the crucial trigger between environmental and economic performance. J. Environ. Manag. 2002, 65, 339-346. [CrossRef]

25. Link, S.; Naveh, E. Standardization and discretion: Does the environmental standard ISO 14001 lead to performance benefits? IEEE Trans. Eng. Manag. 2006, 53, 508-519. [CrossRef]

26. Barla, P. ISO 14001 certification and environmental performance in Quebec's pulp and paper industry. J. Environ. Econ. Manag. 2007, 53, 291-306. [CrossRef]

27. Nguyen, Q.A.; Hens, L. Environmental performance of the cement industry in Vietnam: The influence of ISO 14001 certification. J. Clean. Prod. 2015, 96, 362-378. [CrossRef]

28. General Statistics Office. Results of the 2017 Economic Census; Statistical Publishing House: Hanoi, Vietnam, 2018. Available online: https://www.gso.gov.vn/en/data-and-statistics/2019/03/results-of-the-2017-economic-census/ (accessed on 15 July 2021).

29. Mohammed, M. The ISO 14001 EMS Implementation Process and Its Implications: A Case Study of Central Japan. Environ. Manag. 2000, 25, 177-188. [CrossRef]

30. Price, T.J. ISO 14001: Transition to champion? Environ. Qual. Manag. 2007, 16, 11-23. [CrossRef] 
31. Le Van, Q.; Viet Nguyen, T.; Nguyen, M.H. Sustainable development and environmental policy: The engagement of stakeholders in green products in Vietnam. Bus. Strateg. Environ. 2019, 28, 675-687. [CrossRef]

32. Tsvetkova, D.; Bengtsson, E.; Durst, S. Maintaining sustainable practices in SMEs: Insights from Sweden. Sustainability 2020, 12, 242. [CrossRef]

33. Evangelista, P.; Durst, S. Knowledge management in environmental sustainability practices of third-party logistics service providers. VINE 2015, 45, 509-529. [CrossRef]

34. Länsiluoto, A.; Järvenpää, M. Environmental and performance management forces. Qual. Res. Account. Manag. 2008, 5, 184-206. [CrossRef]

35. Carroll, A.B. The pyramid of corporate social responsibility: Toward the moral management of organizational stakeholders. Bus. Horiz. 1991, 34, 39-48. [CrossRef]

36. Freeman, R.E. The politics of stakeholder theory: Some future directions. Bus. Ethics Q. 1994, 4, 409-421. [CrossRef]

37. Friedman, M. The social responsibility of business is to increase its profits. In Corporate Ethics and Corporate Governance; Springer: Berlin/Heidelberg, Germany, 2007; pp. 173-178.

38. Davidson III, W.N.; Worrell, D.L. Regulatory pressure and environmental management infrastructure and practices. Bus. Soc. 2001, 40, 315-342. [CrossRef]

39. Enquist, B.; Johnson, M.; Skålén, P. Adoption of corporate social responsibility-Incorporating a stakeholder perspective. Qual. Res. Account. Manag. 2006, 3, 188-207. [CrossRef]

40. Bansal, P.; Roth, K. Why companies go green: A model of ecological responsiveness. Acad. Manag. J. 2000, 43, 717-736.

41. Pan, J. A comparative study on motivation for and experience with ISO 9000 and ISO 14000 certification among Far Eastern countries. Ind. Manag. Data Syst. 2003, 103, 564-578. [CrossRef]

42. Hart, S.L. A natural-resource-based view of the firm. Acad. Manag. Rev. 1995, 20, 986-1014. [CrossRef]

43. Porter, M.; Van der Linde, C. Green and competitive: Ending the stalemate. Harv. Bus. Rev. 1995, 73, 120-133.

44. Shrivastava, P. Environmental technologies and competitive advantage. Strateg. Manag. J. 1995, 16 (Suppl. 1), 183-200. [CrossRef]

45. Oxborrow, L.; Brindley, C. Adoption of "eco-advantage" by SMEs: Emerging opportunities and constraints. Eur. J. Innov. Manag. 2013, 16, 355-375. [CrossRef]

46. Van Hemel, C.; Cramer, J. Barriers and stimuli for ecodesign in SMEs. J. Clean. Prod. 2002, 10, 439-453. [CrossRef]

47. Rand, J.; Tarp, F. Characteristics of the Vietnamese Business Environment: Evidence from a SME Survey in 2015; Central Institute for Economic Management: Hanoi, Vietnam, 2007.

48. Anh Van, N.T.; Hieu, N.K. Factors Affecting the Achievement of Environmental Standard Certificates (ESC) at Small and Medium Vietnamese Enterprises. In Proceedings of the 2018 4th International Conference on Green Technology and Sustainable Development (GTSD), Ho Chi Minh City, Vietnam, 23-24 November 2018; pp. 460-465. [CrossRef]

49. Rezaee, Z.; Elam, R. Emerging ISO 14000 environmental standards: A step-by-step implementation guide. Manag. Audit. J. 2000, 15, 60-67. [CrossRef]

50. Hoang-Anh, H. Business Compliance with Environmental Regulations: Evidence from Vietnam; Gothenburg: Ho Chi Minh City, Vietnam, 2015.

51. Cohen, M.A.; Fenn, S.; Naimon, J.S. Environmental and Financial Performance: Are They Related? Investor Responsibility Research Center, Environmental Information Service: Washington, DC, USA, 1995.

52. Cassells, S.; Lewis, K. SMEs and environmental responsibility: Do actions reflect attitudes? Corp. Soc. Responsib. Environ. Manag. 2011, 18, 186-199. [CrossRef]

53. Al-Najjar, B.; Anfimiadou, A. Environmental policies and firm value. Bus. Strateg. Environ. 2012, 21, 49-59. [CrossRef]

54. Freedman, M.; Jaggi, B. Pollution disclosures, pollution performance and economic performance. Omega 1982, 10, 167-176. [CrossRef]

55. Ingram, R.W.; Frazier, K.B. Environmental performance and corporate disclosure. J. Account. Res. 1980, 18, 614-622. [CrossRef]

56. Burke, S.; Gaughran, W.F. Developing a framework for sustainability management in engineering SMEs. Robot. Comput. Integr. Manuf. 2007, 23, 696-703. [CrossRef]

57. Vernon, J.; Essex, S.; Pinder, D.; Curry, K. The 'greening' of tourism micro-businesses: Outcomes of focus group investigations in South East Cornwall. Bus. Strateg. Environ. 2003, 12, 49-69. [CrossRef]

58. Yacob, P.; Wong, L.S.; Khor, S.C. An empirical investigation of green initiatives and environmental sustainability for manufacturing SMEs. J. Manuf. Technol. Manag. 2019, 30, 2-25. [CrossRef]

59. Fadly, D. Greening industry in Vietnam: Environmental management standards and resource efficiency in SMEs. Sustainability 2020, 12, 7455. [CrossRef]

60. Cascio, J. The ISO 14000 Handbook; ASQ: Milwaukee, WI, USA, 1996; ISBN 0873894405.

61. Marcus, P.A.; Willig, J.T. Moving Ahead with ISO 14000: Improving Environmental Management and Advancing Sustainable Development; John Wiley \& Sons: San Francisco, CA, USA, 1997; Volume 4, ISBN 0471168777.

62. Woodside, G.; Aurrichio, P. ISO 14001 Auditing Manual; McGraw Hill Professional: New York, NY, USA, $2000 ;$ ISBN 0071349073.

63. Cheremisinoff, N.P.; Bendavid-Val, A. Green Profits: The Manager's Handbook for ISO 14001 and Pollution Prevention; Elsevier: Amsterdam, The Netherlands, 2001; ISBN 0080507603.

64. Morris, A.S. ISO 14000 Environmental Management Standards: Engineering and Financial Aspects; John Wiley \& Sons: San Francisco, CA, USA, 2004; ISBN 0470090774. 
65. Sheldon, C. ISO 14001 and Beyond: Environmental Management Systems in the Real World; Routledge: London, UK, 2017; ISBN 1351283367.

66. Heras-Saizarbitoria, I.; Molina-Azorín, J.F.; Dick, G.P.M. ISO 14001 certification and financial performance: Selection-effect versus treatment-effect. J. Clean. Prod. 2011, 19, 1-12. [CrossRef]

67. Del Brìo, J.A.; Junquera, B. A review of the literature on environmental innovation management in SMEs: Implications for public policies. Technovation 2003, 23, 939-948. [CrossRef]

68. Le, D.V.; Le, H.T.T.; Pham, T.; Van Vo, L. Access to Finance and Innovation in Small and Medium Enterprises-Evidence in Vietnam. SSRN Electron. J. 2019. Available online: https:/ / papers.ssrn.com/sol3/papers.cfm?abstract_id=3450916 (accessed on 15 July 2021).

69. Luu, H.N.; Nguyen, L.Q.T.; Vu, Q.H.; Tuan, L.Q. Income diversification and financial performance of commercial banks in Vietnam: Do experience and ownership structure matter? Rev. Behav. Financ. 2019, 12, 185-199. [CrossRef]

70. Đạt, T.T.; Trường, Đ.Đ. Green Growth Towards Sustainable Development in Vietnam. VNU J. Soc. Sci. Humanit. 2013, $29,1-14$.

71. Hillary, R. ISO 14001: Case Studies and Practical Experiences; Routledge: London, UK, 2017; ISBN 1351282751.

72. Rehfeld, K.-M.; Rennings, K.; Ziegler, A. Integrated product policy and environmental product innovations: An empirical analysis. Ecol. Econ. 2007, 61, 91-100. [CrossRef]

73. Coughlan, A.T.; Schmidt, R.M. Executive compensation, management turnover, and firm performance. An empirical investigation. J. Account. Econ. 1985, 7, 43-66. [CrossRef]

74. Lausten, M. CEO turnover, firm performance and corporate governance: Empirical evidence on Danish firms. Int. J. Ind. Organ. 2002, 20, 391-414. [CrossRef]

75. $\mathrm{Wu}, \mathrm{M}$.-W.; Shen, C.-H. Corporate social responsibility in the banking industry: Motives and financial performance. J. Bank. Financ. 2013, 37, 3529-3547. [CrossRef]

76. Kamasak, R. The contribution of tangible and intangible resources, and capabilities to a firm's profitability and market performance. Eur. J. Manag. Bus. Econ. 2017, 26, 252-275. [CrossRef]

77. Margaritis, D.; Psillaki, M. Capital structure, equity ownership and firm performance. J. Bank. Financ. 2010, 34, 621-632. [CrossRef]

78. Jadiyappa, N.; Jyothi, P.; Sireesha, B.; Hickman, L.E. CEO gender, firm performance and agency costs: Evidence from India. J. Econ. Stud. 2019, 46, 482-495. [CrossRef]

79. Vu, T.-H.; Nguyen, V.-D.; Ho, M.-T.; Vuong, Q.-H. Determinants of Vietnamese Listed Firm Performance: Competition, Wage, CEO, Firm Size, Age, and International Trade. J. Risk Financ. Manag. 2019, 12, 62. [CrossRef]

80. Becker, G.S. Human Capital: A Theoretical and Empirical Analysis, with Special Reference to Education, 3rd ed.; The University of Chicago Press: Chicago, IL, USA, 2002.

81. Peni, E. CEO and Chairperson characteristics and firm performance. J. Manag. Gov. 2014, 18, 185-205. [CrossRef]

82. General Statistics Office of Vietnam (GSO). Business Establishments. In Results of Establishment Census of Vietnam 2002; Statistical Publishing House: Hanoi, Vietnam, 2004.

83. General Statistics Office of Vietnam (GSO). The Real Situation of Enterprises through the Results of Surveys Conducted in 2005, 2006, 2007; Statistical Publishing House: Hanoi, Vietnam, 2008. Available online: https://www.gso.gov.vn/en/data-and-statistics/20 19/03/2232/ (accessed on 15 July 2021).

84. White Paper: Small and Medium Enterprises in Vietnam; Agency for Enterprise Development: HaNoi, Vietnam, 2014; Available online: https:/ / www.economica.vn/Portals/0/Documents/VN\%20SME\%20White\%20Book\%202014Available\%20online (accessed on 15 July 2021).

85. Bostian, M.; Färe, R.; Grosskopf, S.; Lundgren, T. Environmental investment and firm performance: A network approach. Energy Econ. 2016, 57, 243-255. [CrossRef]

86. Aron, D.J. Ability, Moral Hazard, Firm Size, and Diversification. RAND J. Econ. 1988, 19, 72. [CrossRef]

87. Porter, M. America's green strategy. Bus. Environ. A Read. 1996, 33, 1072.

88. Akhtar, I.; Nazir, N. Effect of waterlogging and drought stress in plants. Int. J. Water Resour. Environ. Sci. 2013, 2, 34-40. [CrossRef]

89. Quesada, C.A.; Miranda, A.C.; Hodnett, M.G.; Santos, A.J.B.; Miranda, H.S.; Breyer, L.M. Seasonal and depth variation of soil moisture in a burned open savanna (campo sujo) in central Brazil. Ecol. Appl. 2004, 14 (Suppl. 4), 33-41. [CrossRef]

90. Masakure, O.; Cranfield, J.; Henson, S. Factors affecting the incidence and intensity of standards certification evidence from exporting firms in Pakistan. Appl. Econ. 2011, 43, 901-915. [CrossRef]

91. Campos, L.M.S. Environmental management systems (EMS) for small companies: A study in Southern Brazil. J. Clean. Prod. 2012, 32, 141-148. [CrossRef]

92. Nakamura, M.; Takahashi, T.; Vertinsky, I. Why Japanese firms choose to certify: A study of managerial responses to environmental issues. J. Environ. Econ. Manag. 2001, 42, 23-52. [CrossRef]

93. Jawahar, I.M.; McLaughlin, G.L. Toward a descriptive stakeholder theory: An organizational life cycle approach. Acad. Manag. Rev. 2001, 26, 397-414. [CrossRef]

94. Blomgren, A. Does corporate social responsibility influence profit margins? A case study of executive perceptions. Corp. Soc. Responsib. Environ. Manag. 2011, 18, 263-274. [CrossRef] 